\title{
“ALLEZ, (MON) CHOU, ON Y VA."”. TWENTY YEARS LATER: REVISITING THE PUZZLE OF FRENCH VOCATIVES
}

\author{
Martine Coene*, Yves D'hulst $^{* *}$, Liliane Tasmowski ${ }^{* * *}$
}

\begin{abstract}
The main assumption put forward in this paper is that that vocative phrases are not substantially different from noun phrases in argument positions when it comes to their internal make-up and the rules underlying their syntactic derivation. Building on evidence coming from different stages and registers of French, two distinct strategies are distinguished that produce determinerless or bare vocatives: the construct state strategy in the case of singular vocatives, and a pronominal complementation strategy in the case of plural vocatives. Although both strategies are different and independent, they share two crucial properties: they both rely on movement to the highest functional projection of the nominal phrase connecting all heads between $\operatorname{Voc}^{0}$ and $\mathrm{N}^{0}$, and they both attribute a special role to the Possessor argument. Against this renewed theoretical background some peculiarities of French vocative constructions are revisited. It is argued that contrary to Old French, in Modern French full N-to-D movement has become obsolete with ordinary common nouns. As in most modern Romance languages, only proper nouns, some diminutives or terms of endearment as well as a handful of kinship terms may still be found in the highest functional layers of the noun phrase. This option is restricted to singular nouns only and heavily relies on the presence of an overt or implicit possessor. Plural bare vocatives are outdated as well, albeit for different reasons. They are analyzed as instances of pronominal complementation. As complemented pronouns are strongly in decline in Modern French, plural bare vocatives follow this downtrend. Modern French offers for both plural bare vocatives and complemented overt pronouns the same alternative strategy: overt realization of the determiner. In the case of vocatives, this alternative is not semantically equivalent, since it does not obligatorily entails a speakeroriented interpretation of the possessive, when PossP is present.
\end{abstract}

Keywords: vocative phrase, construct state, pronominal complementation, movement, Possessor

\section{Introduction}

Back in 1983, Levinson referred to the vocative as "an interesting grammatical category, yet underexplored." For the last twenty years, however, there has been quite some interest into the peculiar interaction between syntax and pragmatics that is at stake when a speaker addresses an interlocutor by means of a so-called vocative phrase. Advances in generative grammar, in particular within the cartographic approach originally presented by Rizzi (1997), have inspired linguists to investigate the grammatical properties of pragmatic markers. Categories with pragmatic functions such as topic or focus that have traditionally remained outside the domain of grammar, have been shown to head their own syntactic projections, on top of morphological categories. Against this background, vocatives have been argued to exhibit a number of pragmatic functions that may relate to their syntactic structure.

Our main assumption is that vocative phrases belong to the nominal domain of grammar, and that their internal make-up as well as the rules underlying syntactic derivation are not substantially different from those that are at stake in noun phrases that

\footnotetext{
*Vrije Universiteit Amsterdam, corresponding author, m.m.r.coene@vu.nl.

${ }^{* *}$ Universität Osnabrück.

${ }^{* * *}$ Universiteit Antwerpen.

Bucharest Working Papers in Linguistics XXI, 2, 101-120, e-ISSN 2392-8093, ISSN-L 2069-9239

DOI: 10.31178/BWPL.21.2.5
} 
are thematically related to the verb, such as subjects and objects. In line with previous work from Longobardi (1994), and our own syntactic analyses of vocative phrases (D'hulst et al., 2007), we take the pragmatic features of vocative phrases to be mapped onto different syntactic categories, creating a very rich functional structure in the left periphery of the noun phrase. We will be revisiting our initial analysis concerning the DP-status of Romance vocatives (Coene et al. 1999), taking into account recent work by Hill (2015) showing that vocative nouns extend into a Vocative Phrase (VocP), saturating the pragmatic role of a speech act predicate in a way similar to the theta-role of a lexical verb.

The question we address concerns the way in which the use of possessives inside vocatives may be accounted for by the syntactic properties of the noun heading the vocative phrase. We will provide two distinct strategies that produce determinerless or bare vocatives: one for singular, the other for plural vocatives. The former strategy was first and most intensively discussed for Romance languages by Longobardi (1994 and especially 2001) and is available in Semitic languages where it is known as construct state. It draws on the presence of an overt or implicit Possessor licensing movement of the noun to $\mathrm{D}^{0}$. The other strategy involves pronominal complementation (we/us Belgians) and was first pointed out by Postal (1966). Although both strategies are different and independent, in the context of vocatives they share a few properties: on the one hand, they rely on movement to the highest functional projection of the nominal phrase, on the other hand, they attribute a special role to the Possessor argument. Against this renewed theoretical background, we will examine some interesting peculiarities of French: first in Modern French, both strategies have become outdated for vocatives containing common nouns, and second, French seems to allow for a seemingly optional use of possessive pronouns overtly expressing the speaker.

The paper is structured as follows. After an examination in section 1 of the internal syntax of vocatives aiming to show that they are full-grown DPs, some recent insights into the external syntax and discursive properties of vocatives are considered in section 2 . The typology of vocatives is discussed in section 3. Sections 4 and 5 address the apparent optionality of determiners in singular and plural vocatives respectively. The conclusions are set out in section 6

\section{Twenty years of research on the internal syntax of vocatives: From DP to VocP}

\subsection{Vocatives are DPs: determinerless vocatives as Romance construct states}

The main claim advanced in our very first paper on vocatives, presented at the 1999 Bucharest Workshop Possession across Romance and Germanic Languages and the 1999 Colloque de Syntaxe et Sémantique in Paris was that vocative phrases project into DPs, just like regular argumental noun phrases (D'hulst et al. 2007). This claim was motivated by two important findings : (i) the occasional overt expression of a definite determiner in nominal expressions of address (1), and (ii) the unavailability of the contrastive reading on post-nominal possessives in vocatives (2): 
(1)

a. French

Allez, les enfants, soyez gentils!

come on-2PL the children be-2PL nice

'Come on, children, be nice!'

b. Romanian

$\mathrm{Nu}$ asta e greşeala ta, băiatule

not here is mistake-the your boy-the.VOC

(2) Italian

'THIS is not your mistake, boy.'

Amico mio, vieni qui! *Mio amico, vieni qui!

friend my/*MY come-2SG here my friend come-2SG here

'Come here, my friend!'

The occurrence of the definite determiner in (1) does not differ from what can be found in noun phrases in argument positions, where the definite determiner may either precede the noun (French, (3a)) or show up as a nominal suffix (Romanian, (3b)). As for the Italian example in (2), the fact that the possessive must appear post-nominally while being incompatible with focus or a contrastive reading strongly contrasts with post-nominal possessives in argumental noun phrases (4), which indeed receive focus and/or a contrastive reading. So, the interpretation of the post-nominal possessive in (2) more closely resembles the interpretation of the prenominal possessive in (4), suggesting that the noun in the vocative moved to a position to the left of the possessive.

a. French

Je n' ai pas vu les enfants.

I NEG have not seen the children

'I haven't seen the children.'

b. Romanian

Băiatul este plecat de $\mathrm{o}$ oră.

Boy-the is left of an hour

(4)

'The boy has left an hour ago.'

Italian
Il mio
amico non è venuto
the my/*MY friend NEG is come
'My friend hasn'ytcome.' the friend MY hasn't come 'MY friend hasn't come.')
$\left(\neq \mathrm{L}^{\prime} \quad\right.$ amico mio non è venuto

On the basis of the above facts, we considered the internal syntax of vocatives to be similar to that of argumental noun phrases, i.e. exhibiting N-to-D movement resulting in a suffixed definite article on common nouns in Romanian on the one hand, and in articleless vocatives with post-nominal non-contrastive possessives in Italian on the other hand. A schematic overview of the respective derivations is given below: 
(5)

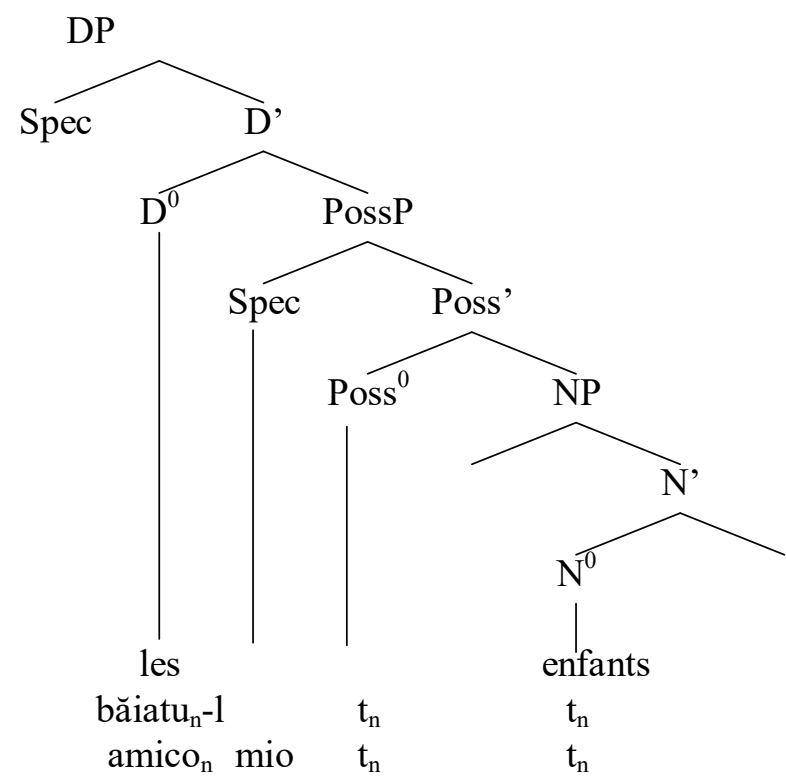

Digging further into the matter, let's turn to Longobardi's (1995) original proposal concerning N-to-D movement in the Romance version of Semitic construct state configurations. A central claim of this study is that determinerless common nouns appearing in $\mathrm{D}^{0}$ discharge a Possessor semantic role on an (understood) genitive modifier, turning them into unambiguous designators of one particular object that is the same in all possible worlds:

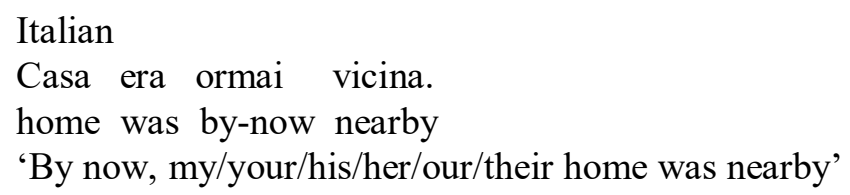

We propose that a similar analysis may hold for French determinerless vocatives: by discharging an understood possessor role, they may designate a referent that has an interpersonal relation with the speaker. This implies that the DP-internal Poss ${ }^{0}$ head does not only check a [Poss]-feature on the noun, but also a Person-feature marked as [1PERSON]. In section 5 we will show that an alternative strategy that applies to bare plural vocatives has effects that are very akin to N-to-D movement and construct state. The fact that the determinerless addressees amis in (7a) can only be interpreted as being the friends of the speaker then naturally follows from the noun's functional structure: by moving to Poss $^{0}$, the noun will check its [1.POSS] features. The fact that the observed referential transparency does not hold for vocative phrases introduced by a definite article may be considered to be the other side of the coin: as such constructions do not require the raising to $\operatorname{Poss}^{0}$ (and in other cases not even the projection of PossP), the addressees 
les amis (7b) do not necessarily have to be the friends of the speaker, but can be merely friends amongst each other:

(7) $\quad \mathrm{a}$
Allons
copains, cessez! Nous partons!
come on-1PL pals stop-2PL we leave-1PL
'Come on, pals, stop it! We are leaving!'

b. Allons les copains, cessez! Nous partons!

come on-1PL the pals stop-2PL we leave-1PL

\subsection{Vocatives are VocPs: An optional layer to encode [2PERSON]}

Up to now, we have argued that some vocatives may arise from syntactic derivations in which the functional head Poss ${ }^{0}$ is the locus where a [1PERSON] of the vocative noun may check part of its conversational pragmatic features. When taking into account the pragmatic features relevant to the interpretation of vocatives, the addressee obviously plays an important role as well. In that respect, Hill (2015) postulates that the [2PERSON] feature maps into syntax in a functional head above $\mathrm{D}^{0}$. She thereby assumes the existence of an optional VocP layer, with $\mathrm{Voc}^{0}$ projecting a phrase structure embedding the DP. Adopting this point of view, we take $\operatorname{Voc}^{0}$ to carry a [2PERSON] feature that may be checked by the noun, and the SpecVocP position to be the locus for (optional) vocative particles.

Under this renewed DP-configuration, French determinerless vocatives undergo movement from $\mathrm{N}^{0}$ to $\mathrm{Voc}^{0}$. In this position they can check their [2PERSON] feature, while vocative particles such as allez 'come on' or hé 'eh' will merge in SpecVocP. These new insights allow us to refine our previously proposed DP internal structure of vocatives in terms of a multilayered functional structure, as depicted in (8), which exhibits a semantico-pragmatic tripartition with respect to the way vocatives refer and are anchored into discourse: (i) the NP-layer is the locus for reference to kind-level individuals; (ii) the DP-layer provides a domain for an object-level interpretation of these expressions, and (iii) the VocP layer will provide these object-referring expressions with additional information with respect to the addressee.

$$
\begin{aligned}
& \text { Allez / Hé, garcon / Louis / toi, vas-y! } \\
& \text { come on-2PL.HON/ eh boy / Louis / you go for it }
\end{aligned}
$$




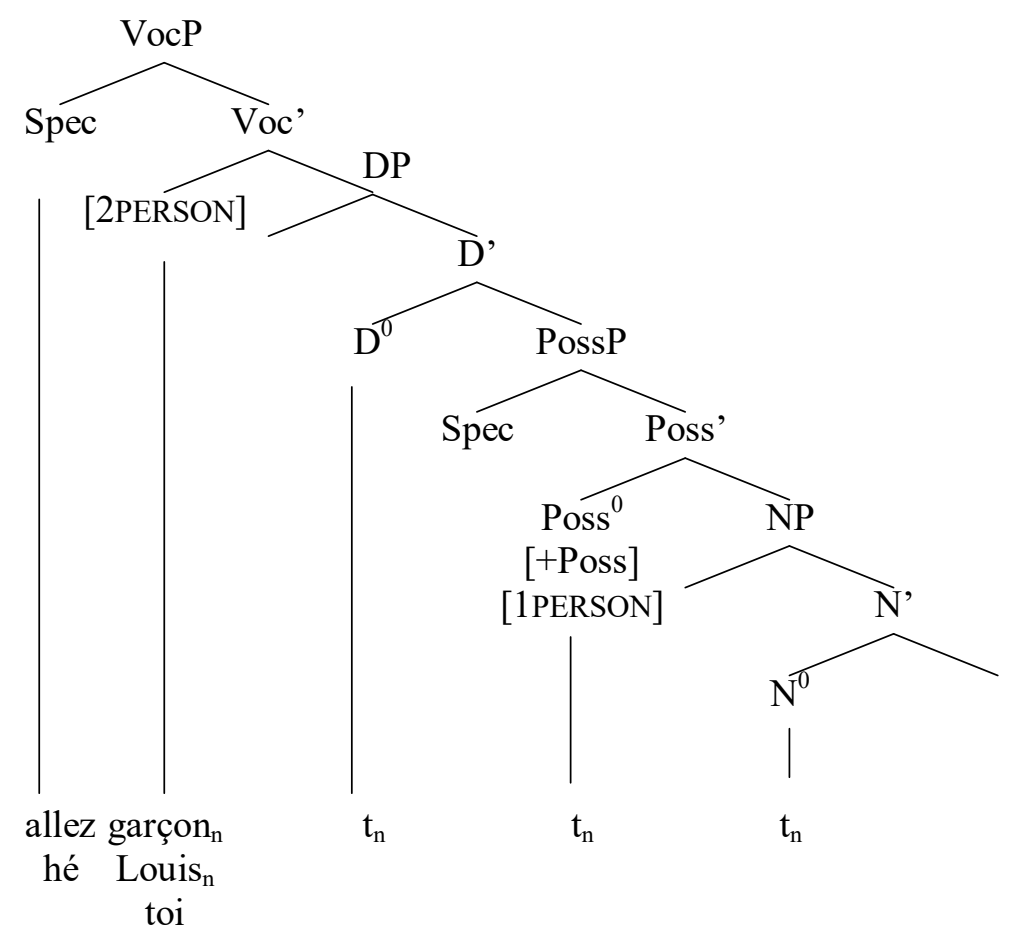

Such an analysis implies that nominal expressions that reach VocP not only exhibit second person semantics but automatically come with an object-level interpretation. Some elements such as pronouns or vocative particles may be taken to be intrinsically marked for 2PERSON and therefore base-generated in VocP, whereas others (e.g. common nouns or proper nouns) may originally be inserted in the lower structural levels and move up to check their relevant referential and pragmatic features.

\subsection{The external syntax of Vocative Phrases: In the C-domain}

Starting point for our analysis of the external syntax of French vocative phrases is Lambrecht's (1994: 268) observations with respect to the similarity between vocatives and topics, stating that "the grammar of vocatives resembles in interesting ways that of TOPIC NPs". Indeed, just like topic NPs, vocative phrases appear either at the left or the right edge of the sentence, and they lack a semantic case role, thereby blocking their referent to be linked to an intra-clausal argument on formal grounds. This may be clearly illustrated by sentences with two left dislocated NPs as in (9), whose referents may be linked to the subject (elle, 'she') or to the object ( $l$ ' 'her') or neither of them. Taking into account that one of the left dislocated NPs may be interpreted as either a vocative phrase or a topic NP, this results in multiple ambiguous readings:

(9) Nicole $_{i, j, x}$, Marie $_{i, j, x}$ elle ne $l_{j}^{\prime}$ aime pas.

Nicole Marie she NEG her loves NEG 
Reading 1:

Nicole $_{\text {TOPj }}$ Marie $_{i}$ elle $_{i}$ ne $l_{j}$ ' aime pas.

'It's Nicole that Marie doesn't like.'

Reading 2:

Nicole $_{\mathrm{i}}$ Marie $_{\text {TOPj }}$ elle $_{i}$ ne $\mathrm{l}_{\mathrm{j}}$ ' aime pas.

'It's Marie that Nicole doesn't like.'

Reading 3:

Nicole $_{\mathrm{VOC}}$ Marie $_{\mathrm{i}}$ elle $\mathrm{e}_{\mathrm{i}}$ ne $\mathrm{l}_{\mathrm{j}}$ 'aime pas.

'Nicole, Marie doesn't like him/her.'

(Lambrecht 1994, ex. (8a))

Lambrecht (1994) convincingly argues that the freedom of semantic linking between topic NPs and vocative phrases with an intra-clausal argument is closely related to the inherently referential nature of both types of expressions. Topics as well as vocative phrases have a uniquely identifiable referent in the discourse. As there is no need to express their relation with the proposition semantically, they function as syntactic adjuncts for which anaphoric linking to an argument in the clause may be established through pragmatic relevance, a pragmatic relation defined in terms of "aboutness" at least as far as the Topic is concerned: a topic is presupposed, followed by a comment stating something about it.

According to Lambrecht (1994) vocatives and topics exhibit striking functional similarities. Contrary to regular adjuncts (10a), they cannot appear in focus positions, as exemplified by $(10 b-c)$ :

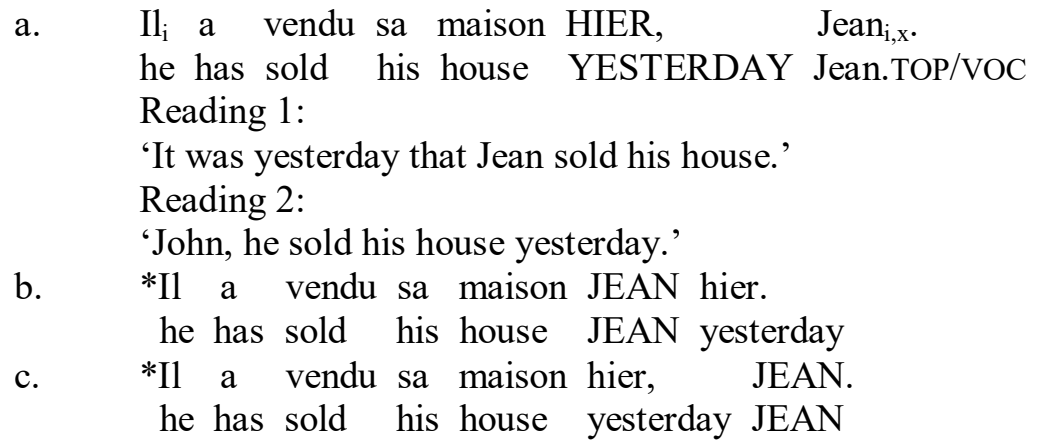

(Lambrecht 1994, ex. (10))

Recently Shormani and Qarabesh (2018) have discussed Yemeni Arabic data that show the similartity of vocatives and aboutness topics. In line with Lambrecht's insights, it is reasonable to claim that in French also, vocatives are a special case of "aboutness topic", and as such they occupy the informational structural layer of the sentence. Within a cartographic approach to syntactic analysis, information coding features such as Topic, Force or Focus, project their own functional projections within the C-domain (Vallduví 1992, Lambrecht 1994, Rizzi 1997, 2004, 2006). Taking into consideration examples such as (11) where only the second term can be understood as Topic, the intrinsic order 
would be Voc-Top. With this in mind, we will follow Espinal (2013) and postulate that vocatives occur in the specifier position of ForceP, a projection above TopP, as shown in (12).

a. Garçon $_{\mathrm{voc}}$, Marie $_{\mathrm{Top}}$, laisse tomber.

boy Marie let fall

$$
\text { 'Boy, let Marie go' }
$$

b. ${ }^{*} \mathrm{Garçon}_{\mathrm{Top}}$, Marie $\mathrm{voc}_{\mathrm{vo}}$, laisse tomber.

boy Marie let fall

'*Marie, let the boy go'

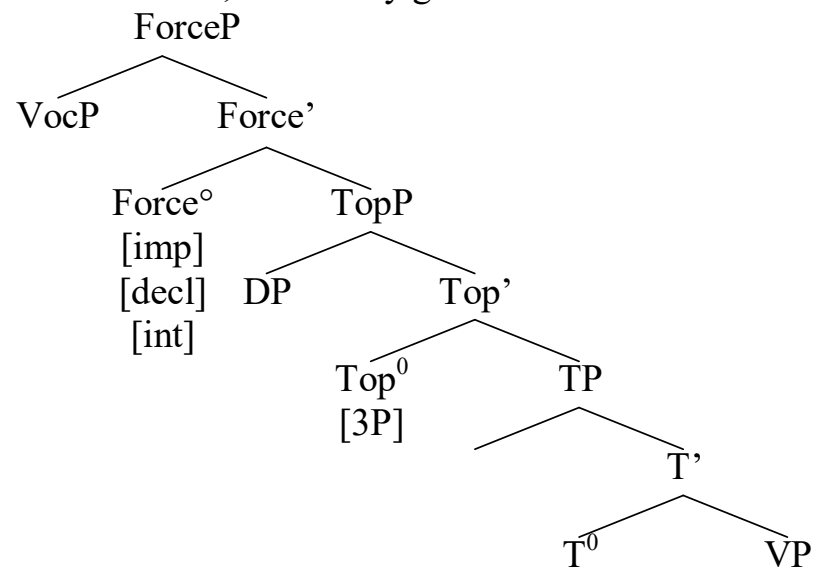

ForceP is endowed with a feature encoding the illocutionary force of the sentence specifying whether it is imperative, declarative or interrogative (Rizzi 1997). Within the proposed syntactic structure, the DP in SpecTop as well as the grammatical subject of the clause may exhibit agreement with the verb independently of the referential content of VocP. The fact that vocatives may still combine not only with imperatives, but also with declaratives and interrogatives is easily accommodated within the proposed layered functional structure. Compare for instance (13a-b) below:

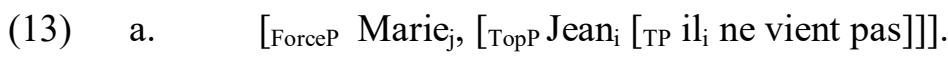

Marie, Jean doesn't come.

b. $\quad\left[\right.$ Forcep $_{\text {Marie }}$, [TорР [TP viens pro ${ }_{i}$ ici $\left.\left.]\right]\right]$ !

Mary, come over here!

c. $\quad\left[\right.$ Forcep Marie $_{i},[$ Topp $[$ TP tu viens ici $\left.]]\right]$ ?

Mary, do you come here?

\section{Revisiting the French puzzle: The seemingly optional use of possessives and determiners}

We will now look in more detail at the variety of possibilities French speakers have to address the addressee. Vocatives may be realized by various nominal categories, such 
as pronouns of address (14), proper nouns (15) and common nouns (16). Pronouns and common nouns appear either in the singular $(14 a, 16 a)$ or the plural $(14 \mathrm{~b}, 16 \mathrm{~b})^{1}$.

(14) a. Tu as un rêve, toi?

you have a dream, you?

b. Et vous, qu'est-ce qui vous a fait changer d' idée and you.PL what.Q you has made change of idea au dernier moment?

at-DEF last moment

'And you, what made you change your mind at the last minute?'

(15) Marie, tu aurais dû venir!

Marie you have-COND need-PTCP come

'Mary, you should have come!'
a. Viens, mon ami.
come, my friend
b. Ecoutez bien, mes potes
Listen well, my pals

Proper and common nouns obey distinct licensing conditions quite generally and their use as vocatives is no exception. Proper names, that are assumed to move from $\mathrm{N}$ to $\mathrm{D}$ in argumental positions (Longobardi 1994), may and most often appear determinerless in vocatives as well, as is the case in (15). Common noun vocatives, however, are subject to additional licensing conditions, requiring the presence of either a possessive (determiner) (17a) with an optional pre- or post-nominal modifier (17b):
a. Viens mon chou, mon bijou, mon joujou, sur mes genoux, come-2SG my cabbage my jewel my toy on my knees et jette des cailloux à ce hibou plein de poux. and throw INDEF pebbles to that owl full of lice
(well-known French mnemonic to learn plural formation)

\footnotetext{
${ }^{1}$ Proper nouns may be assumed to be intrinsically singular (i). Whenever they occur in the plural, they seem to behave semantically and syntactically as common nouns, either taking the definite article when they are interpreted as definite (iia), or receiving the same interpretations as bare common nouns (iib):

(i) John is fond of Italy.

(ii) a. I didn't see *(the) Annas.

We learned about *(the) Americas last year.

b. $\quad$ The place was full of Johns

The examples in (iii) with optional determiners in front of nationality nouns are interesting for sure, but it is unlikely that they represent instances of true proper names. If this were the case, we couldn't understand why examples like (iv) are ruled out.

(iii) a. Américains, admettez que le superflu allège l'âme.

'Americans, admit that the excess alleviates the soul.'

b. Allez, les Belges!

(Jean Cocteau. Lettre aux Américains. 1949)

'Come on, Belgians!

*Annas, come on now!
} 
b. Tiens, ma jolie maman, voici des roses blanches! take my lovely mother look INDEF roses white 'Please, dear mother, I've got you some white roses!' Venez, mes bébés d' amour. come-2PL my babies of love 'Come, my darling babies.'

A limited list of singular and plural common nouns are exempt from this additional restriction. They include a variety of hypocoristics, especially terms of endearment (18a), relational bare singulars (and plurals) (18b) and some bare plurals (18c) (see also (7a)). Bare hypocoristics are alive and kicking in the modern language, but bare singular and plural non-hypocoristic vocatives are nowadays considered archaic or very formal as illustrated by the examples in (18b-c).

a. Viens, chou, qu'est-ce que tu es heureux chez Mamie! come cabbage what.Q/EXCL you are happy at granny 'Come here, darling! How happy you are to be at granny's!'

Viens, bijou, viens ma belle, viens voir où je vis. come jewel come my beautiful come see where I live 'Come here, pearl! Come here beautiful girl, come see where I live.'

Viens, fifille / poulette / fiston.

come girlie/ chick / sonny

'Come little girl / chick / little son'

b. Laisse-moi faire, ami, je travaille pour toi. let me do friend I work for you 'Let me handle it, (my) friend, I'm working for you.'

(V. Hugo Ruy Blas. 1838; Frantext)

Père, glorifie ton Fils de la gloire que j'ay possédée en toy devant que les fondemens du monde fussent assis!

'Father, glorify your son with the glory that I have owned in you before the world's foundations were layed down!'

(J. Calvin. Institution de la religion chrestienne I. 1560; Frantext)

c. Bien vu, pas vrai camarades?

well seen not true comrades

'Well seen, isn't it, comrades?'

(G. de Pirexécourt. Victor ou l'enfant de la forêt. 1789; Frantext) Bonaparte prit la parole: «Soldats, dit-il, je vous ai menés à la victoire, puis-je compter sur vous?»

"Bonaparte took the floor: "Soldiers, he said, I have led you to victory, can I count on you?"”

(F.A. Mignet. Histoire de la révolution française. 1824; Frantext) 


\section{Gradual loss of N-to-Voc movement}

In what follows, we will attribute the apparent inconsistencies in the use of bare nouns vs. nouns accompanied by some modifier in French vocatives to an ongoing process of loss of movement of N-to-Voc.

First, consider how the paradigms of the possessive forms in the older stages of French combined with nouns in argument positions. In the earliest stages of the language, the inherited Latin possessive pronouns had developed into two paradigms, one composed of atonic forms of the type mon, ton, son, etc. (accusative forms) and another one composed of tonic forms. The first series (19a) occurred exclusively in prenominal position and could not be combined with an overt determiner. ${ }^{2}$ Arteaga and Herschensohn (2016) qualify them as clitics in Cardinaletti and Starke's (1999) sense; we will call them "possessive determiners". The tonic forms of the other series typically combined with various sorts of determiners (definite and indefinite articles, demonstratives, nominal quantifiers etc.), as illustrated in (19b, c). According to Arteaga and Herschensohn (2016) they qualify as weak forms; we will call them "possessive adjectives".

(19) a. Old French:

si cum om per dreit son fradra saluar dift

(Oaths of Strasboug, 12 February 842)

Modern French:

comme on doit, conformément au droit, soutenir son frère

'As, by law, one ought to protect one's brother.'

b. ces deux vostres colonels

these two your colonels

'these two colonels of yours'

(attributed to Rabelais. In M. Galliot 1967: 324, quoted in Miguel 2002)

c. Quand vous dictes devant luy quelque mien affere que nul

when you say in.front of him some my case that no

aultre ne voulut fere;

other NEG want-PST make

'when you state in front of him a certain case of mine that no other would take care off'

(Pierre Sala. Le Chevalier au Lion. 1522?, in Miguel 2002)

The optional use of the determiner with possessive adjectives, created in Old French a partial functional overlap between both possessive series. But from the $16^{\text {th }} \mathrm{C}$. onwards, a

\footnotetext{
${ }^{2}$ Marchello-Nizia (1979), Martin and Wilmet (1980) and Skårup (1994) observe that there are a few examples of clitic possessives accompanied by determiners. They appear only in a few texts of the $15^{\text {th }} \mathrm{C}$., most prominently in the Cent nouvelles nouvelles by Philippe Pot (1486) (Skårup 1994). This latter reference is interesting, in the light of Skärups observation that this particular syntax might have been an Italianism, since the Cent nouvelles nouvelles were heavily inspired by Italian literature. Posner's (1997) remark that clitic and weak possessives had basically the same distribution in Old French should be interpreted in this perspective.
} 
categorial change took place that primarily affected the possessive adjective (Posner 1997): it was ever more often found in combination with a determiner, and could be used either in combination with a noun or in elliptic constructions, functioning as a possessive pronoun (this is actually the context that survives in modern French).

In Old French the regular position of the possessive adjectives was prenominal. Skårup (1984: 98, fn. 1), following Marchello-Nizia (1979) and Martin and Wilmet (1980), observes that the post-nominal position becomes steadily more frequent from the second half of the $14^{\text {th }} \mathrm{C}$ onwards. Consider in this respect (20) below:

(20) Où je vacqué \& mainte \& mainte année, / Accompagnée de l' ame where I strayed \& many \& many years / accompanied of the soul à tout bien née / $D^{\prime}$ un frère mien, lequel a mérité / to all well born / of a brother my the-which has merited/ D' avoir honneur à la postérité. of have honour to the posterity

(Guy Le Fevre de la Boderie. Diverses meslanges poétiques. 1582)

As in modern Italian, the difference between pre- and post-nominal positions was presumably one of contrastive stress. Both its distribution and its alleged interpretation suggest that already in Middle French possessive adjectives had shifted from weak to strong status (see also Arteaga 1995 and Arteaga and Herschensohn 2016).

Strikingly, in the same language stage, in vocatives, possessive adjectives could only occur in post-nominal position (21). And just as strikingly, the interpretation of such possessives corresponds to the non-contrastive reading of prenominal adjectival possessives embedded in argument position (19).

$$
\begin{aligned}
& \text { Ha! frère mien, tu ne dois faire plainte. } \\
& \text { ah friend my / *MY you NEG need make complaint }
\end{aligned}
$$

(Pierre de Ronsard. Les æuvres. 1584)

If we assume that the non-contrastive possessive adjective in (21) occupies the same position as the non-contrastive possessive adjective in (19), the difference in word order must be the consequence of movement of the noun to $\mathrm{D}^{0}$, crossing over the possessive, and admittedly further to $\operatorname{Voc}^{0}$, as shown below. 
(22)

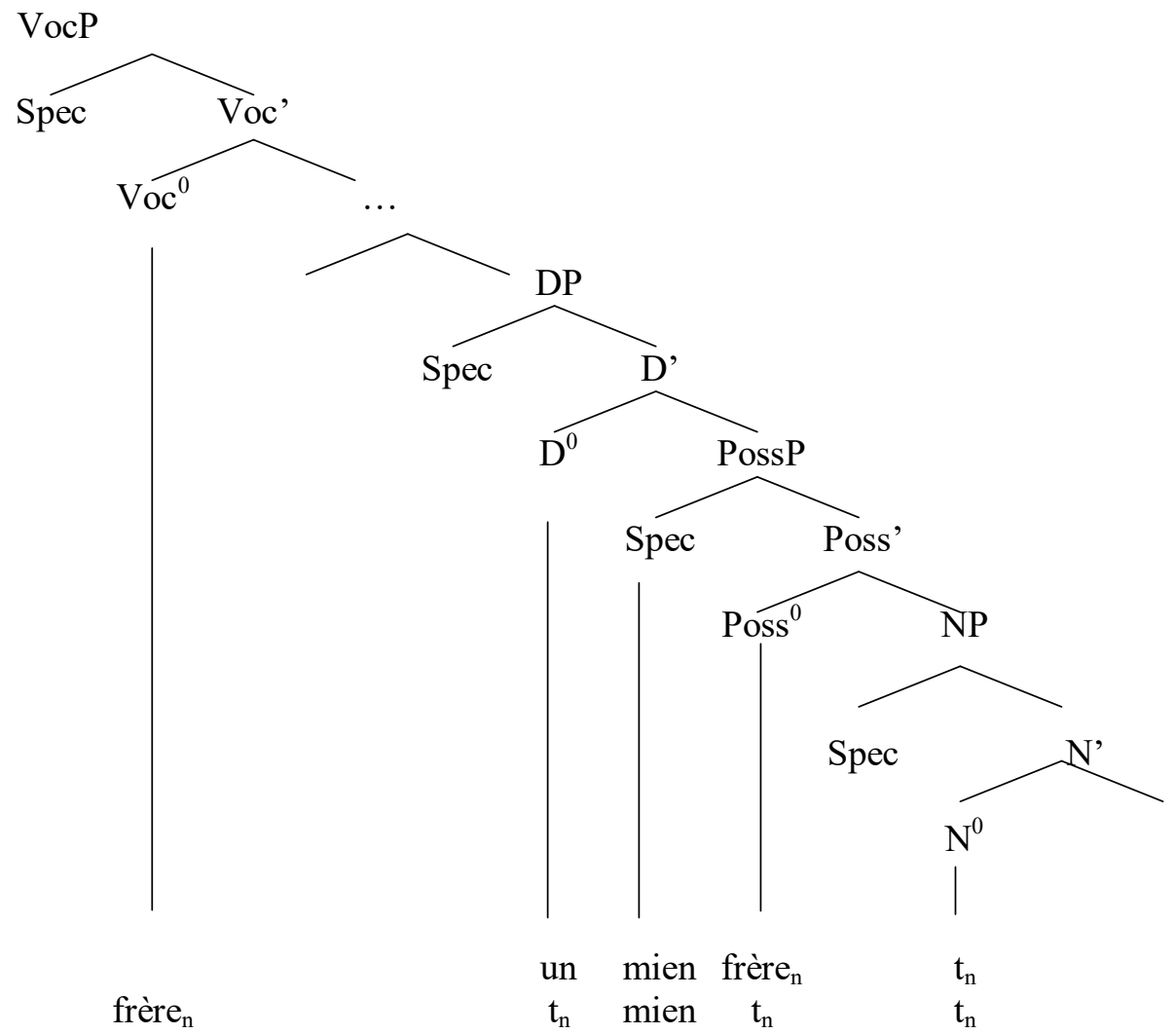

Since possessive determiners occupy $\mathrm{D}^{0}$, they block the full raising of the noun illustrated in (22) and strand the noun in an intermediate functional position below $\mathrm{D}^{0}$, resulting in word order phenomena as those observed in (23): possessive determiner noun - adjective:
Mon ami cher, par bon eür,
soiez joieus et asseür, my friend dear by good hour [= luck] be-2PL merry and certain car feite es amie novelle je, sui Marie la pucelle,... while made is friend new I am Marie the virgin (Jean le Marchant. Miracle de Notre-Dame de Chartres. 1262; manuscript lost, oldest copy $14^{\text {th }} \mathrm{C}$.)

Eventually Modern French will fully differentiate the two series of possessives, reserving the possessive determiner to fully-fledged noun phrases and reducing the possessive adjective to elliptical contexts, where they will act more or less as possessive pronouns $^{3}$.

\footnotetext{
${ }^{3}$ In Modern French, the singular possessives mien, sien and very rarely tien can be used in front of the noun in high standard registers in combination with a definite article (ia-b). In all other cases (ic-d), possessive
} 


\section{MARTINE COENE, YVES D'HULST, LILIANE TASMOWSKI}

Against this historical background we can now address the earlier mentioned "optionality" of the possessive determiner omission in Modern French vocatives. Reexamining the examples in (17) vs. (18), we note that, in general, the $\mathrm{D}^{0}$ position of vocatives must be lexically filled by a definite or a possessive determiner, much like the head of DPs in argument positions. Only a highly limited number of kinship terms and diminutives that may serve as quasi proper nouns are exempt from the obligatory use of a determiner.

Within the above-discussed N-to-D movement approach, fiston and fifille in (18a) are base generated in $\mathrm{N}^{0}$ and move all the way up in the functional structure to $\mathrm{D}^{0}$ and admittedly to $\operatorname{Voc}^{0}$, just like frère 'brother' in (21). They can do so, because, following Longobardi $(1995,2001)$, (singular) common nouns only raise to $\mathrm{D}^{0}$ if an overt or understood genitive argument is realized. Terms of endearment fulfill this requirement, because (i) the very notion of endearment implies an Experiencer argument (the person, whom the referent of the noun phrase is dear to) and (ii) this experiencer argument can be identified in a straightforward manner: the experiencer argument of endearment terms is strictly speaker-oriented. The latter aspect can best be demonstrated with kinship terms like mother (father etc.) and the corresponding endearments mommy (daddy, etc.). Both are relational terms and therefore require the identification of an additional argument in order to be properly interpreted (*the/his mother/mommy was sad) (see Delfitto and D'hulst 1995). However, while mother establishes a specific genealogical relationship between two individuals in a neutral or objective way, mommy does so only indirectly: mommy is the person I can say mommy to (because she is my mother). In other words, mother has two arguments and mommy has three with the relational argument anaphorically bound to the experiencer argument.

Summarising, of the four nouns inserted in vocative position in (24), only the first two may be used without determiner, Mary because (personal) proper names move to $\mathrm{D}^{0}$ by default and chou because terms of endearment discharge an Experiencer role that can be properly identified. Kinship terms like fille are no longer supported in Modern French, because the relational argument cannot be inherently identified and non-kinship terms like enfant are pragmatically odd due to the fact that they do not obligatorily discharge a Possessor argument.

adjectives are highly infrequent and considered as a kind of "fetched use of the language" (Grevisse and Goosse 2008: 793: "pour imiter le langage paysan", 'to imitate the farmers' language use').

(i) a. Le patron jura qu' un vieux sien matelot était un cuisinier estimable. the chief swore that an old his sailor was a cook great

(P. Merimée. Colomba. 1840, in Grevisse and Goosse 2008, §613)

b. J' ai retrouvé l' autre jour un mien article.

I have found the other day a my paper

(H. de Montherlant. Le solstice de juin. 1941, in Grevisse and Goosse 2008, §613)

c. priant Dieu de lui pardonnerles siennes fautes pareillement

praying God of him-DAT forgive the HIS sins similarly

(G. Sand. François le Champi. 1848, in Grevisse and Goosse 2008, §613)

d. Cette mienne vie trop connue

this my life too known

(M. Proust. À la recherche du temps perdu. 1913-1927, in Grevisse and Goosse 2008, §613) 


$$
\begin{array}{ll}
\text { Allez, } & \text { Marie / chou } / *_{\text {fille }} /{ }^{?} * \text { enfant, viens ici! } \\
\text { come on-2PL.HON Marie / darling } / * \text { girl } /{ }^{?} * \text { child } & \text { come here }
\end{array}
$$

The corollary of (24) is that nouns that may discharge an additional argument are all licensed in contexts where an overt possessive is realized. This is the case for all common nouns, because they either must (terms of endearment and relational nouns) or may (non-relational nouns) discharge an additional argument. Proper names cannot in principle discharge an additional possessive argument and thus are excluded in the context of an overt possessor.

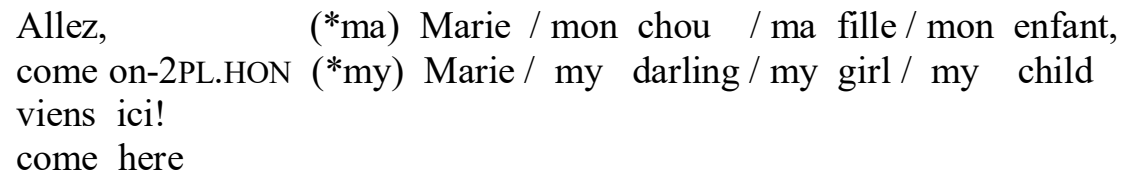

\section{Plural determinerless vocatives}

In this final section, we will address the plural vocatives without determiner of examples (7a) and (18c). In Modern French these bare vocatives constitute a marked option and are mostly considered as "outdated", "high register" or "literary" use. But even as a marked option, they are problematic for our general assumption that vocatives contain a DP- (and eventually a VocP-) layer above NP, because, as is well known, French is extremely reluctant to bare plurals in general. Furthermore overt N-to-D movement has been shown to be limited to (singular) proper nouns and a selected class of singular common nouns (Longobardi 1994, 2001) and no evidence whatsoever has been put forward that shows that plural nouns undergo overt N-to-D movement in Romance. A further problematic factor is that plural vocatives may appear determinerless in all other Romance and Germanic languages with prenominal determiners. Therefore, the analysis of examples (7a) and (18c) must follow from more generally available linguistic options than the highly constrained $\mathrm{N}^{\mathrm{O}}$-to- $\mathrm{D}^{\mathrm{O}}$ movement for common nouns.

Our analysis of bare plural vocatives will be based on two distinct phenomena: (i) imperatives allow for empty subjects (see Jensen 2003, Bennis 2007 for more detailed argumentation) and (ii) pronouns are regular DPs in their own right and may allow for complementation (an idea based on an original insight of Postal 1966, and integrated by many authors within the DP-hypothesis). Both phenomena are not language specific and will thus ensure that our analysis may carry over to other Romance and Germanic languages.

Complementation of pronouns is restricted to first and second person plural pronouns, as shown in (26) for Italian. In French 1PL or 2PL pronouns may be complemented as well, as shown in (27a), but their use is rather marked and archaic, and they will be more often substituted by combinations of pronouns and full DPs like those in (27b). 

a. [DP noi / voi [NP italiani] $]$ we/ you.PL Italians
b. $\quad\left[\mathrm{DP}_{\text {io }} / \mathrm{tu}\right.$ / lui / lei / loro $\left[\mathrm{NP}_{\mathrm{N}}\right.$ italiano / a / i / e $\left.]\right]$ I / you.SG / he / she / they Italian(s)

a. J' aurais, à coup sûr, souhaité que vous Américains,

I have-1SG.COND for sure, wished that you Americans les Anglais et nous Français, ..., nous nous accordions the English and us French we us.REFL agree-1PL.SBJV pour mener une action dans cette affaire. to undertake an action in this matter

(C. de Gaulle. Lettres, notes et carnet 9, Janvier 1961 - décembre 1963. Paris: Plon. 1986; Letter addressed to John F. Kennedy. February 6, 1961)

b. Vous les Américains et nous les Français you-PL the Americans and we the French

Note that bare vocatives like (7a) and (18c) and complemented pronouns like (27a) have two properties in common: both are archaic in Modern French and both are naturally substituted by expressions containing an overtly realized determiner (7b/27b). As these two properties are language-specific, we feel confident to presume a natural relationship between them.

Our main assumption is that empty pronouns are not different from regular pronouns and can be complemented as well. However, we expect the complementation of pro to be severely restricted: for one thing, we do not only expect complementation of pro to be limited at the best to 1PL and 2PL interpretations, just as regular pronouns, but we also expect their interpretation to be fully recoverable in a very limited set of contexts only. If complementation of pro were possible under ordinary conditions, bare plural subjects should be allowed in all pro-drop languages, contrary to fact (see (28)). In other words, the recovery of pro's features by verbal morphology, i.e. an external source, as in highly inflected languages like Italian, is insufficient to allow for complementation.

$$
\begin{aligned}
& \text { *[Dp pro } \left.\left[{ }_{\mathrm{NP}} \text { balene }\right]\right] \text { sono dei mammiferi. } \\
& \text { pro whales are INDEF mammals }
\end{aligned}
$$

If external identification of pro is insufficient, the only remaining option for complementation is that pro is identified internally. This will dramatically narrow down the contexts where pro can be complemented; one context, and perhaps even the only one, is that of vocatives where $\operatorname{Voc}^{0}$ is inherently and universally endowed with a [2PERSON] feature. Without additional structure above DP, pro cannot be identified but externally and therefore will never complement, but in VocP the features of $\operatorname{Voc}^{0}$ will fully recover the person feature of pro and thereby render complementation possible. The internal structure of such a complemented pro is sketched out in (29): pro originates as $\mathrm{D}^{0}$, just like full pronouns, and raises to $\operatorname{Voc}^{0}$ where it is identified by the [2PERSON] feature, thereby allowing for an optional complement NP. 


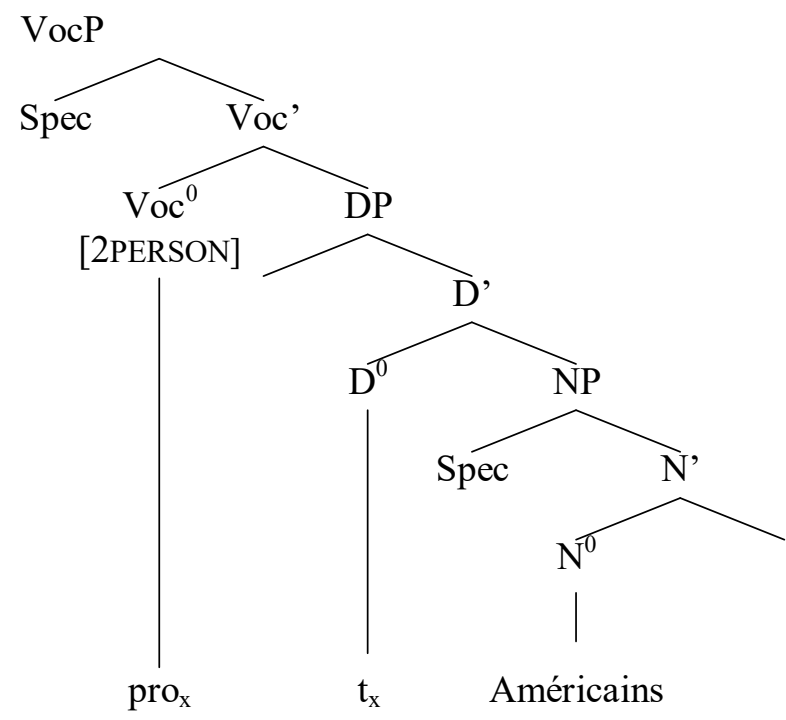

With relational nouns like ami 'friend' (7a) or camarade 'comrade' (18c), the presence of an intermediate functional layer, PossP, forces the complement noun to raise to $\operatorname{Poss}^{0}$, in order for all heads to be properly connected. The possessive [1PERSON] feature of Poss $^{0}$ will generate the speaker-oriented possessive reading of these structures; as explained before. ${ }^{4}$

\footnotetext{
${ }^{4}$ The option of inserting a PossP layer remains of course available for non-relational nouns as well. This might be the proper interpretation of the second example in (18c) where the soldiers are of course Napoleon's. The movement of $\mathrm{N}^{0}$ to Poss ${ }^{0}$ might be responsible for an extraordinary semantic effect that pops up in vocatives. Although vocatives are inherently 2 PERSON, bare plurals (and also vocatives with overt possessors) are admitted in hortatives as well:

(i) Rallions-nous à notre antique bannière, soldats français; marchons ensemble au unite us.REFL to our old flag soldiers French walk together to-the renversement de la tyrannie! overthrow of the tyranny

(F. P. Lubis, Histoire de la restauration 11. Paris: Roland Desbarres 1848: 122) The vocative in (i) is strictly interpreted as a $2 \mathrm{PL}$ form, but is also connected to the subject of the hortative which must be 1PL. The association of a $2 \mathrm{PL}$ form to a $1 \mathrm{PL}$ subject may be facilitated by the representation of the 2 PERSON feature in $\operatorname{Voc}^{0}$ and the 1PERSON feature in Poss ${ }^{0}$. Note that a similar analysis could be pursued for the second example in (18c). This line of analysis may find support in the fact that both in the example above and in the second example in (18c) the person uttering the imperative is the commander of the troops, the Duke of Angoulême and Napoleon respectively, hence a soldier himself. Note furthermore that overt 2PL pronouns may not occur as vocatives in hortatives, in spite of the fact that $2 \mathrm{PL}$ pronouns may be complemented as in (27), and the fact that they may be used as vocatives in other contexts. Interestingly, 2PL pronouns cannot be combined with relational nouns either: *vous amis/copains/camarades. The correct empirical observation seems to be that the fuzziness concerning the person identification cannot be lexical, but must be triggered structurally by expressions that are unspecified for person and therefore compatible with both specifications in the appropriate syntactic context: pro and common nouns.
} 
(30)

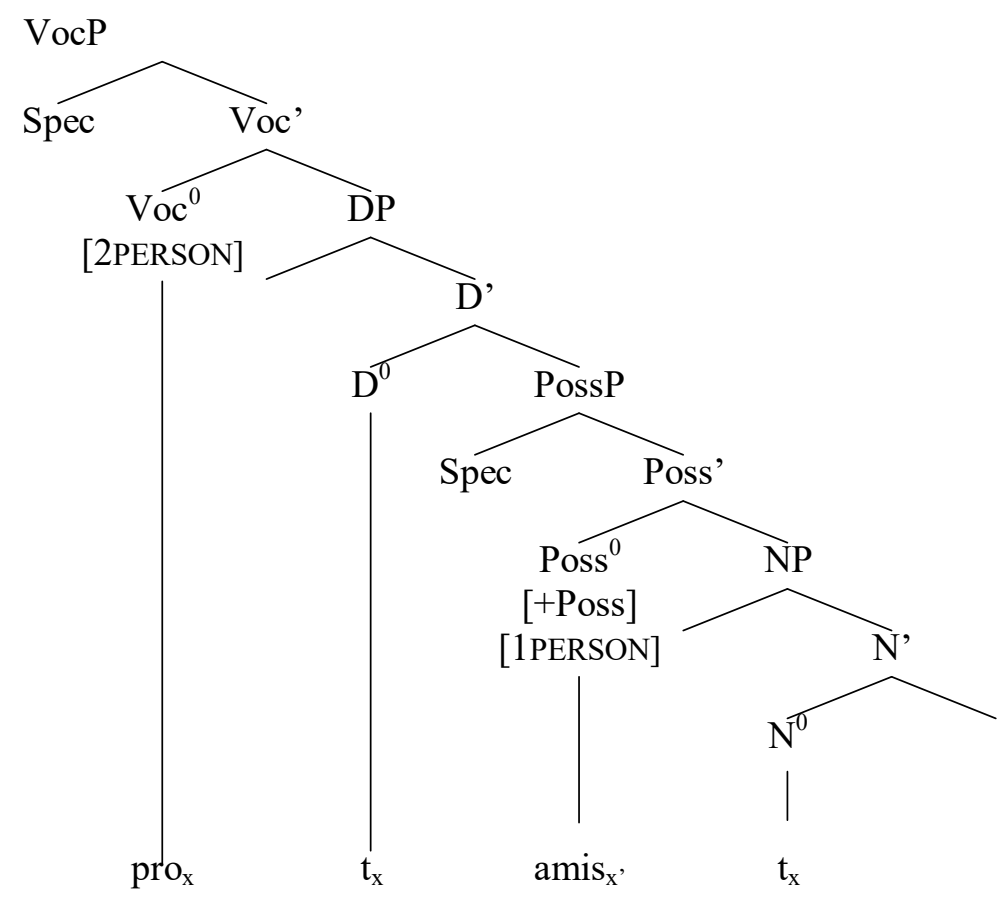

Summarizing, bare plural vocatives are in principle allowed under the analysis where pro raises to $\operatorname{Voc}^{0}$ and is complemented by a common noun in $\mathrm{N}^{0}$, raising to Poss ${ }^{0}$ when present. In Modern French, these vocatives have become rare, just as complemented pronouns, and we may expect both to eventually become inexistent in later stages of the language.

\section{Conclusions}

Getting back to our initial puzzle concerning the seeming optionality of determiners in some vocative constructions in Modern French, all elements now seem to fall into place. Contrary to Old French, in Modern French full N-to-D movement has become obsolete with ordinary common nouns. As in most modern Romance languages, only proper nouns, some diminutives or terms of endearment as well as a handful of kinship terms may still be found in the highest functional layers of the noun phrase. This option is restricted to singular nouns only and heavily relies on the presence of an overt or implicit possessor.

Plural bare vocatives are outdated as well, albeit for different reasons. We have analyzed them as instances of a more generally available strategy of pronominal complementation. And since complemented pronouns are strongly in decline in Modern French, we naturally expect plural bare vocatives to follow this downtrend. Modern French offers for both plural bare vocatives and complemented overt pronouns the same alternative strategy: overt realization of the determiner. In the case of vocatives, this 
alternative is not semantically equivalent, since it does not obligatorily entails a speakeroriented interpretation of the possessive, when PossP is present.

Both strategies, N-to-D-to-Voc movement (singular vocatives) and pronominal complementation (plural vocatives), share a crucial property: all heads between $\operatorname{Voc}^{0}$ and $\mathrm{N}^{0}$ are properly connected: either directly through movement of a single category (singular bare vocatives) or indirectly through movement of pro, predication by $\mathrm{N}^{0}$ and, whenever functional categories intervene between $\mathrm{D}^{0}$ and $\mathrm{N}^{0}$, movement of $\mathrm{N}^{0}$ to Poss ${ }^{0}$.

A straightforward connection (or chain) between $\operatorname{Voc}^{0}$ and $\mathrm{N}^{0}$ is necessary for the proper interpretation of vocatives. With the exception of overt pronouns (which also raise from $\mathrm{D}^{0}$ to $\mathrm{Voc}^{0}$ ), none of the other categories occurring in vocatives, pro and proper names, are intrinsically specified for person. To acquire a 2PERSON interpretation they must connect to the 2PERSON feature in $\operatorname{Voc}^{0}$. This can be achieved either by movement alone (singular vocatives) or by movement and standard predication (plural vocatives).

\section{References}

Arteaga, D. 1995. On Old French genitive constructions. In J. Amastae, G. Goodall, M. Montalbetti and M. Phinney (eds.), Contemporary Research in Romance Linguistics, 79-90. Amsterdam/Philadelphia: John Benjamins.

Arteaga, D. and Herschensohn, J. 2016. Old French possessives and ellipsis. In C. Tortora, M. den Dikken, I. L. Montoya and T. O'Neill (eds.), Romance Linguistics 2013. Selected Papers from the 43rd Linguistic Symposium on Romance Languages (LSRL), New York, 17-19 April, 2013, 21-38. Amsterdam/Philadelphia: John Benjamins.

Bennis, H. 2007. Featuring the subject in Dutch imperatives. In W. van der Wurff (ed.), Imperative Clauses in Generative Grammar: Studies in Honour of Frits Beukema, 113-134. Amsterdam/Philadelphia: John Benjamins.

Cardinaletti, A. and Starke, M. 1999. The typology of structural deficiency: A case study of the three classes of pronouns. In H van Riemsdijk (ed.), Clitics in the Languages of Europe, 145-233. Berlin: Mouton de Gruyter.

Delfitto, D. and D'hulst, Y. 1995. On the syntax of null possessive anaphors. Recherches de linguistique française et romane d'Utrecht (Utrecht Studies in Romance Linguistics) 14: 13-38.

D'hulst, Y., Coene, M. and L. Tasmowski. 2007. Romance vocatives and the DP hypothesis. In A. Cuniță, C. Lupu and L. Tasmowski (eds.), Studii de lingvistică şi filologie romanică. Hommages offerts à Sanda Reinheimer-Rîpeanu, 200-211. Bucharest: Editura Universităţii din Bucureşti.

Espinal, T. 2013. On the structure of vocatives. In B. Sonnenhauser and P. N. A. Hanna (eds.), Vocative!: Addressing between System and Performance, 109-132. Berlin - Boston: De Gruyter Mouton.

Galliot, M. 1967. Études d'ancien français. Paris: Didier.

Grevisse, M. and Goosse, A. 2008. Le Bon Usage, fourteenth edition. Bruxelles: De Boeck.

Hill, V. 2007. Vocatives and the pragmatics-syntax interface. Lingua 117 (12): 2077-2105.

Hill, V. 2013. Features and strategies: The internal syntax of vocative phrases. In B. Sonnenhauser and P. N. A. Hanna (eds.), Vocative! Addressing between system and performance, 133-156. Berlin - Boston: De Gruyter Mouton.

Hill, V. 2015. Vocatives: How Syntax Meets with Pragmatics. Leiden: Brill.

Jensen, B. 2003. Syntax and semantics of imperative subjects. Nordlyd 31 (1): 150-174.

Jensen, F. 1990. Old French and Comparative Gallo-Romance Syntax. Tübingen: Max Niemeyer.

Lambrecht, K. 1994. Information Structure and Sentence Form: Topic, Focus and the Mental Representation of Discourse Referents. Cambridge: Cambridge University Press.

Lambrecht, K. 1996. On the formal and functional relationship between topics and vocatives. Evidence from French. In A. Goldberg (ed.), Conceptual Structure, Discourse and Language, 267-288. Stanford, CA: CSLI Publications.

Levinson, S. C. 1983. Pragmatics. Cambridge: Cambridge University Press. 
Longobardi, G. 1994. Reference and proper names: A theory of N-movement in syntax and logical form. Linguistic Inquiry 25 (4): 609-665.

Longobardi, G. 2001. Formal syntax, diachronic minimalism, and etymology: The history of French chez. Linguistic Inquiry 32 (2): 275-302.

Marchello-Nizia, C. 1979. Histoire de la langue française aux XIV et XV siècles. Paris: Bordas.

Martin, R. and Wilmet, M. 1980. Manuel du français du Moyen Âge, vol. 2, Syntaxe du moyen français. Bordeaux: Sobodi.

Miguel, M. 2002. Possessive pronouns in European Portuguese and Old French. Journal of Portuguese Linguistics 1: 215-240.

Ménard, P. 1980. Manuel du français du Moyen Âge, vol. 1, Syntaxe de l'ancien français. Bordeaux: Sobodi.

Moignet, G. 1988. Grammaire de l'áncien français. Paris: Klincksieck.

Posner, R. 1997. Linguistic Change in French. Oxford: Clarendon Press.

Postal, P. M. 1966. On so-called 'pronouns' in English. In F. P. Dineen (ed.), Report of the Seventeenth Annual Roundtable Meeting on Linguistics and Language Studies, 177-206. Washington, DC: Georgetown University Press.

Rizzi, L. 1997. The fine structure of the left periphery. In L. Haegeman (ed.), Elements of Grammar, 281-339. Dordrecht: Kluwer.

Rizzi, Luigi, and Bocci, G. 2017. The left periphery of the clause - Primarily illustrated for Italian. In M. Everaert and H.C. van Riemsdijk (eds.), The Wiley Blackwell Companion to Syntax, second edition, John Wiley \& Sons. DOI: 10.1002/9781118358733.wbsyncom104.

Shormani, Q. and Qarabesh, M. A. 2018. Vocatives: Correlating the syntax and discourse at the interface. Cogent Arts \& Humanities 5. DOI: 10.1080/23311983.2018.1469388.

Skårup, P. 1994. Morphologie synchronique de l'ancien français. Copenhagen: Munksgaard.

Vallduví, E. 1992. The Information Component. New York: Garland. 